\title{
SH2B2 Gene
}

National Cancer Institute

\section{Source}

National Cancer Institute. SH2B2 Gene. NCI Thesaurus. Code C21303.

This gene is involved in signal transduction and plays a role in insulin-mediated glucose uptake. 